\title{
MELATIH KESABARAN DAN WUJUD RASA SYUKUR SEBAGAI MAKNA COPING BAGI ORANG TUA YANG MEMILIKI ANAK AUTIS
}

\author{
ANGGIA KARGENTI EVANURUL MARETTIH \\ UIN-SUSKA Riau, Indonesia \\ anggiaken@yahoo.co.id/anggia.kargenti@uin-suska.ac.id \\ SRI RAHMI WAHDANI \\ UIN-SUSKA Riau, Indonesia \\ srirahmi.wahdani@yahoo.com
}

\begin{abstract}
This study aimed to find out what is the meaning of coping strategies among parents with autism child. The study involved four informants (two married couples who have children with autism), whose were obtained by purposive sampling. This study used a qualitative phenomenological approach. Data analysis used in-depth interview,were using time triangulation andresource triangulation for the credibility of data.The results concluded that the parents were meaning their coping as a way to increase their patience, as a gratitute for their amazing gift, and realize the importance of social support from others to rise up child with autis. There is a differences between mother and father'scoping. Mothers are more likely to use problem focused coping, while fathers tend to use emotional focused coping.
\end{abstract}

Key words: Coping, Parents, Child with Autism

\begin{abstract}
ABSTRAK
Penelitian ini bertujuan untuk mengetahui apa makna coping serta manfaat coping yang dilakukan oleh orang tua yang memiliki anak autisme. Informan terdiri dari empat (4) orang, yang merupakan pasangan suami istri yang memiliki anak autis, dengan menggunakan purposive sampling. Penelitian ini menggunakan metode kualitatif fenomenologi. Teknik pengumpulan data dilakukan dengan wawancara mendalam. Dari hasil penelitian dapat disimpulkan bahwa orang tua memaknai coping sebagai pembelajaran untuk melatih kesabaran, wujud rasa syukur serta menyadari pentingnya dukungan sosial dari orang lain dalam mengasuh anak autis. Pemaknaan coping bagi orang tua merupakan sebuah proses pengalaman dan pembelajaran bidup yang akan meningkatkan kapasitas internal mereka. Bersyukur atas anugerah anak yang telah diberikan Tuban menjadi ajang untuk melatih kesabaran diri, sehingga mereka mampu menjalankan perannya sebagai orangtua dengan baik dan benar. Ada perbedaan copingyang dilakukan oleh orangtua dalam menghadapi, merawat dan mengasuh anak autis. Coping Ibu lebih cenderung kepada problem focused coping, sedangkancoping ayah cenderung pada emotional focused coping.
\end{abstract}

Kata Kunci: Coping, Orang Tua, Anak Autis 


\section{A. PENDAHULUAN}

Setiap orang tua sudah barang tentu menginginkan dan mengharapkan anak yang dilahirkan akan tumbuh menjadi anak yang menyenangkan, terampil dan pintar sehingga nantinya akan menjadi penerus dalam keluarga. Namun, Beberapa orang tua justru mendapat anak yang memiliki kekurangan. Salah satu bentuk kekurangan atau kelainan tersebut adalah gangguan perkembangan seperti autisme. Ibu yang memiliki anak yang mengalami disabilitas/kecacatan akan cenderung mengalami stres lebih besar (Goldenberg, 1992). Sejalan dengan Goldenberg, Mancil, Boyd, Bedesem (2009) menjelaskan bahwa orangtua dengan anak berkebutuhan khusus seperti autisme akan lebih rentan untuk mengembangkan stres dalam kehidupan keluarga dibandingkan orang tua dari anak-anak dengan gangguan perkembangan selain autis. Hal ini menegaskan bahwa, memiliki anak autis merupakan sebuah cobaan sekaligus tantangan bagi orang tua.

Gangguan autisme merupakan salah satu gangguan perkembangan pervasif, berawal sebelum usia 2,5 tahun. Gejala-gejala utamanya adalah ketidakmampuan untuk berhubungan dengan orang lain, berbagai masalah komunikasi, mencakup kegagalan dalam mempelajari bahasa atau ketidakwajaran bicara, seperti ekolalia, dan pembalikan kata ganti; dan mempertahankan kesamaan, suatu keinginan obsesif untuk mempertahankan rutinitas sehari-hari dan lingkungan sekelilingnya selalu sama persis (Davidson, 2010). Autisme merupakan suatu gangguan perkembangan pervasive yang ditandai dengan ketidakmampuan anak dalam berkomunikasi, baik verbal maupun non verbal, mengalami hambatan dalam interaksi sosial serta menunjukkan tingkah laku yang tidak biasa (DSM IV-TR 2000). Anak autisme seperti memiliki dunianya sendiri sehingga asyik dengan dunianya sendiri tanpa menghiraukan sekitarnya. Mereka menikmati dunia yang mereka miliki, dan tidak mempedulikan orang lain, sehingga gagal melakukan interaksi sosioemosional.

Seperti yang dituliskan sebelumnya, orang tua yang memiliki anak autis memiliki risiko tinggi untuk mengembangkan stres dalam kehidupan keluarga dibandingkan orang tua dari anak-anak dengan gangguan perkembangan lainnya (Mancil Boyd, Bedesem, 2009). Namun demikian Dunn et al (2001), menjelaskan bahwa sumber yang tepat dari pemicu stres mereka belum dapat dipastikan hanya saja kemungkinan besar disebabkan kesulitan untuk menemukan diagnosa yang tepat dan akurat tentang karakteristik anak, serta kesulitan dalam mengakses dukungan sosial. Hal ini menyebabkan orang tua harus 
melakukan upaya pengatasan masalah atau coping yang tepat sehingga dapat mengurangi tekanan dan stres yang dirasakan.

Konsep upaya pengatasan masalah ini disebut dengan strategi coping. Lazarus (1993) mengatakan bahwa, coping dapat didefinisikan sebagai upaya kognitif dan perilaku yang sedang berlangsung untuk mengelola tuntutan eksternal dan atau internal yang spesifik yang dinilai berat atau melebihi sumber daya seseorang.

Menurut Richard Lazarus dan rekan-rekannya, terdapat dua jenis coping (Cohen \& Lazarus, 1979; Lazarus \& Folkman, 1984; Lazarus \& Launier, 1978) yang masingmasing disebut dengan Problem Focused Coping dan Emotional Focused Coping (Sarafino, 1997). Problem-Focused Coping (PFC) merupakan strategi pemecahan masalah yang berfokus pada bagaimana cara individu untuk menghadapi sumber masalah penyebab stres secara langsung dengan mengganti sumber masalah ke dalam beberapa cara lain. Dengan menghadapi masalah, individu mampu mengurangi efek dari stress yang dialami.Emotional-Focused Coping merupakan strategi pemecahan masalah yang berfokus pada mengurangi tekanan emosional yang dirasakan oleh individu. Ketika mampu mengontrol emosi, maka individu akan dapat mengubah cara menghadapi sumber masalah penyebab stres sehingga mengurangi efek negatif dari sumber stress tersebut.

Setiap orang tua pasti memiliki upaya penyelesaian masalahnya masing-masing. Lazarus dan Folkman (1987) menjelaskan bahwa, perbedaan jenis kelamin memberikan kontribusi besar dalam hal menentukan bentuk coping yang akan dilakukan. Perempuan lebih cenderung menggunakan emotional focused coping untuk mengatasi situasi stres, sementara laki-laki lebih menggunakan problem focused coping. Kecenderungan perempuan menggunakanemotion focused coping tidak hanya disebabkan sumber stres yang berbeda, melainkan juga tipe kepribadian yang berbeda antara perempuan dan lakilaki (Greenglass, 1993).

Wardani (2009) dalam penelitiannya menemukan bahwa, pada umumnya sebagian besar orang tua yang memiliki anak autis memempunyai orientasi penyelesaian masalah yang berfokus pada cara atau strategi untuk menyelesaikan masalah (Problem Focused Coping). Bentuk-bentuk usaha yang dilakukan antara lain: berusaha mencari informasi tentang bagaimana cara menangani anak, bagaimana cara penyembuhan untuk anak, dan juga pendidikan yang bagaimana yang cocok untuk anak, mencari tempat terapi dan juga 
sekolah khusus untuk anak, serta memberikan pengertian tentang keadaan anak mereka pada masyarakat dengan baik-baik.

Sejalan dengan Wardani, Amalia (2012) dalam penelitiannya menemukan bahwa, orang tua melakukan coping tergantung pada kondisi dan situasi apa yang menekan pada saat itu. Orang tua baik ayah maupun ibu mengupayakan pengatasan masalah dengan menggunakan emotional focused coping maupun problem focused coping sesuai dengan apa yang dibutuhkan sebagai pengatasan masalah. Upaya pengatasan masalah yang dilakukan orangtua dalam bentuk emotional focused coping antara lain seperti; menenangkan diri, banyak berdoa dan berserah kepada Tuhan, mencari bantuan dari ahli, membaca buku, menciptakan makna positif dari permasalahan yang dihadapi, serta berinteraksi dengan orang tua lain yang mengalami situasi yang sama. Sementara itu, pengatasan masalah dengan problem focused coping yang dilakukan orangtua dalam mencari tahu informasi dan hal-hal apa yang dapat dan mampu mereka lakukan sebagai orang tua untuk membantu mengembangkan kemampuan yang dimiliki anak mereka.

Demikian juga penelitian Ramadhany \& Marettih (2009) yang menyimpulkan bahwa memiliki anak autis mendorong ibu untuk melakukan coping sebagai upaya mereka dalam mengatasi permasalahan mereka sehingga terhindar dari kondisi distres. Sumber stres akan mengarahkan ibu untuk memutuskan strategi coping yang akan digunakan baik dalam bentuk emotional focused coping maupun problem focused coping, sebagai upaya ibu untuk menyembuhkan anak mereka sehingga anak dapat tumbuh dan berkembang normal seperti anak-anak lainnya.

Kepedulian ibu terhadap kesembuhan anaknya yang menderita autis, dianggap sebagai bentuk tanggung jawab ibu dalam pengasuhan anak sesuai peran gendernya sebagai perempuan. Peran gender merupakan peran dalam ruang dan/ atau porsi tertentu bagi laki-laki maupun perempuan yang dikonstruksikan oleh sosial, masyarakat dan budaya. Artinya, sesuai dengan peran gender yang disematkan kepada perempuan, sebagai ibu, perempuan harus lebih peduli terhadap kegiatan domestik dalam hal ini mengurus rumah tangga, seperti mengurus anak dibanding ayah, yang secara konstuksi budaya dianggap bertanggung jawab di ruang publik.

Lazarus \& Folkman (1984), menjelaskan bahwa usaha pengatasan masalah yang dilakukan individu untuk menangani situasi penuh tekanan ditentukan oleh beberapa sumber daya individu yang meliputi: a) Kesehatan dan tenaga, yang merupakan hal yang penting, karena selama dalam usaha mengatasi stres individu dituntut untuk 
mengerahkan tenaga yang cukup besar; b) Keyakinan atau pandangan positif yang berfungsi sebagai dasar timbulnya harapan untuk melakukan coping ketika individu menghadapi kondisi yang buruk; c) Kemampuan memecahkan masalah sebagai kemampuan individu untuk mencari informasi, menganalisis situasi untuk tujuan mengidentifikasi masalah untuk menentukan alternatif tindakan, menimbang alternatif tindakan yang akan dilakukan, dan perencanaan tindakan yang tepat (Janis \& Mann, 1977); d) Keterampilan Sosial, meliputi kemampuan untuk berkomunikasi dan bertingkah laku dengan cara-cara yang sesuai dengan nilai-nilai sosial yang berlaku di masyarakat; e) Dukungan soscial merupakan pemenuhan kebutuhan informasi dan emosional pada diri individu yang diberikan oleh orang tua, anggota keluarga lain, saudara, teman, dan lingkungan masyarakat sekitarnya; dan f) Materi, hal ini meliputi sumber daya berupa uang, barang-barang atau layanan yang biasanya dapat dibeli. Kenyataan bahwa anak yang diinginkan menjadi kebanggaan justru menderita autisme yang bahkan untuk berinteraksi dengan orang lain saja sulit, menyebabkan orang tua harus membuang jauh harapannya.Untuk itu, baik ibu maupun ayah membutuhkan suatu strategi penyelesaian terhadap masalah yang timbul selama mengasuh anak autis.

Penelitian ini menfokuskan pada bagaimana kedua orang tua, baik sebagai ayah maupun ibu memaknai coping yang dilakukan pada anak mereka yang mengalami autis. Tujuan dari penelitian ini adalah untuk mengetahui apa makna coping yang dilakukan oleh orang tua yang memiliki anak autisme, serta apakah ada manfaat coping yang dilakukan.

\section{B. TINJAUAN PUSTAKA}

\section{Permasalahan yang Dihadapi Orang Tua yang Memiliki Anak Autis}

Berbagai permasalahan akan dihadapi para orang tua ketika memiliki anak dengan gangguan autisme seperti:

\section{a. Ketidakmampuan orang tua dalam memahami komunikasi anak}

Autisme merupakan gangguan pervasif yang ditandai dengan adanya hendayadalam komunikasi, anak autis menunjukkan ketidakmampuan dalam menyampaikan maksud atau keinginan dengan bahasa yang sulit dipahami, sehingga orang tua merasa sulit dalam melakukan komunikasi dengan anak karena sulit untuk memahami penyampaian anak autisme. 


\section{b. Kesulitan orang tua dalam menangani anak ketika mengalami temper tantrum}

Merawat anak autisme merupakan hal yang menyenangkan sekaligus menantang. Banyak hal yang tidak terduga akan temui orang tua dalam merawat anak autis. Namun demikian, orang tua kerap mengalami kesulitan mengatasi anak autis karena kerap kali dihadapkan dengan perilaku tantrum yang dilakukan seperti mencakar, menggigit, memukul, menendang, bahkan dalam beberapa kasus, anak dengan gangguan autisme kerap menyakiti diri sendiri dengan cara membenturkan kepala, serta menendang, memukul dan mencubiti diri sendiri ketika merasa kesal. Tidak jarang, anak menunjukkan perilaku tantrum ketika apa yang diinginkan tidak didapatkan. Tantrum adalah ledakan emosi yang ditandai dengan gejala keras kepala, menangis, menjerit, menantang, dan berteriak-teriak marah (Hurlock, 2000). Ketika tantrum, biasanya orang tua akan mengalami kesulitan, karena tidak tahu apa yang diinginkan anak, hal ini terjadi karena anak mengalami kegagalan dan hambatan dalam menjelaskan apa yang diinginkan dan tidak mampu menjelaskan apa yang tidak disukainya. kurangnya pengetahuan orang tua terhadap anak autisme serta kondisi anak yang sulit berkomunikasi bahkan melakukan tindakan yang menyakiti diri sendiri dan orang lain menyebabkan orang tua mengalami kebingungan bahkan merasakan stres menghadapi perilaku tantrum anak.

\section{Coping}

Dalam penelitian ini ditemukan bahwa, banyak cara yang telah dilakukan oleh orang tua yang memiliki anak autisme dalam menangani masalah yang dialami terkait dengan penyelesaian yang berpusat pada masalah (Problem Focused Coping):

a. Assistance seeking, orang tua menggunakan bantuan dari pihak lain dengan cara mencari dukungan berupa nasihat untuk menghadapi permasalahannya, seperti menentukan langkah seperti apa yang tepat dalam upaya penanganan terhadap anak autisme.

b. Information seeking, orang tua berupaya untuk mencari infromasi dari mendatangi dokter, membaca buku, majalah, hadir di seminar, hingga mencari informasi dari internet.

c. Direct action, orang tua memasukkan anak ke sekolah dan terapi, dan mempersiapkan terkait masa depan anak dalam menjalani kehidupannya. Selain 
itu, coping dalam bentuk Direct Action juga dilakukan oleh orang tua ketika sedang menghadapi anak autisme yang sedang tantrum, seperti membekap anak dengan tujuan untuk menenangkan, agar anak tidak sampai menyakiti diri sendiri, juga menenangkan anak dengan cara mengelus penuh sayang agar tantrum anak mereda.

d. Turning to religion, berdoa serta berserah diri kepada Tuhan atas kondisi anak, yang mana orang tua mencari ketengan dan bantuan dari Tuhan dengan cara berdoa, ataupun beribadah.

Selain itu, informan juga melakukan pengatasan masalah yang berorientasi pada emosi (Emotional Focused Coping) sebagai berikut:

a. Self criticism, di mana orang tua sempat menyalahkan diri sendiri yang berdampak pada pemikiran serta perasaan yang dipenuhi kesedihan.

b. Denial, orang tua merasa sulit menerima kenyataan bahwa anak mengalami gangguan perkembangan, sehingga pada awalnya bersikeras menganggap anak sama dengan anak normal lain seusianya.

c. Possitive reappraisal, menganggap kehadiran anak pembawa rezeki bagi keluarga serta bersyukur diberikan kesempatan untuk memiliki anak dengan fisik sempurna meski autism

Tabel 1. Perbedaan Coping Ayah dan Ibu

\begin{tabular}{lll}
\hline & \multicolumn{1}{c}{$\boldsymbol{P F C}$} & \multicolumn{1}{c}{$\boldsymbol{E F C * *}$} \\
\hline Ayah & $\begin{array}{l}\text { 1. Seeking Emotional } \\
\text { asistance }\end{array}$ & 1. Denial \\
& 2. Turning to religion & 2. Avoidance \\
& 3. Possitive reappraisal \\
& 4. Blaming self/Self critism \\
\hline Ibu & $\begin{array}{l}\text { 1. Seeking emotional } \\
\text { asistance }\end{array}$ & 1. Blaming self/Self critism \\
& 2. Seeking information & \\
3. Direct action & \\
4. Turning to religion & \\
*Problem focused coping &
\end{tabular}

Dari tabel 1, dapat disimpulkan bahwa walaupun ayah dan ibu menggunakan coping yang bervariasi, namun ayah lebih cenderung menggunakan emotional focused coping dan ibu lebih cenderung menggunakan problem focused coping.

\section{Makna Coping bagi Orang Tua yang Memiliki Anak Autis}

Tidak mudah menjadi orang tua dari anak autisme, orang tua diharuskan untuk selalu memiliki kesehatan prima baik fisik maupun psikis untuk mengasuh anak 
dengan baik. Coping orang tua yang memiliki anak autis merupakan upaya-upaya yang dilakukan oleh orang tua untuk mengatasi tekanan yang disebabkan oleh permasalahan yang dihadapi dalam merawat, mengasuh dan mendidik anak autis.

Berikut ini makna coping bagi orang tua yang memiliki anak autis:

Kesabaran; anak autisme sangat membutuhkankepedulian, perhatian, pendidikan, serta pelatihan khusus yang bukan hanya dalam jangka waktu yang singkat saja, melainkan sepanjang hidupnya. Proses dari terapi yang cukup memakan waktu lama serta konsistensi untuk mengulang program terapi di rumah juga menjadi tuntutan tersendiri bagi orang tua. Perilaku tantrum pada anak autisme juga menjadi salah satu kendala bagi orang tua. Namun, hal-hal tersebut dimaknai oleh orang tua sebagai wadah untuk melatih kesabaran. Mubarok (2009) berpendapat bahwa sabar adalah tabah hati tanpa mengeluh dalam menghadapi godaan dan rintangan dalam jangka waktu tertentu, dalam rangka mencapai tujuan. Menghadapi anak yang membutuhkan perlakuan khusus, mengajarkan orang tua untuk menjadi pribadi yang lebih bersabar. Kesabaran orang tua sangat diperlukan dalam menjalani kehidupan sehari-hari bersama anak autisme.

Rasa syukur; anak adalah nikmat Allah SWT yang harus disyukuri, karena tidak semua pasangan suami istri dapat memiliki anak keturunan.Meski anak terlahir dengan gangguan autisme, orang tua menyadari sepenuhnya bahwa masih banyak ayah dan ibu diluar sana yang merindukan kehadiran anak, dan jikapun telah memiliki anak. Memiliki anak dengan kondisi fisik anak yang normal, terlebih lagi anugerah dikaruniai seorang anak dalam rumah tangga merupakan hal yang memang sudah patut untuk disyukuri. Dari keadaan anak yang autisme, orang tua menjadi lebih mensyukuri nikmat serta keadaan yang sudah dimiliki saat ini. Anak mengajarkan orang tua untuk lebih bersyukur.

Membutuhkan dan mencari dukungan sosial lingkungan; orang tua menyadari bahwa dalam proses pengasuhan anak selama ini banyak memerlukan tenaga dari pihak lain yang tidak akan dapat dinilai hanya dengan materi. Diperlukan tenaga terapis, tenaga pengajar disekolah, maupun kehadiran keluarga yang senantiasa bersedia memberi pertolongan untuk menjaga anak dikala orang tua merasa lelah. Orang tua, baik ayah maupun ibu berusaha untuk mencari bantuan profesional yang dapat mereka untuk mendidik keterampilan anak. Dukungan sosial yang paling penting adalah yang diberikan pasangan (suami kepada istri dan istri kepada suami). 
Ibu mengupayakan agar anak mereka tumbuh dan berkembang seperti anak normal lainnya, walaupun tidak dapat normal sepenuhnya, tetapi ibu optimis bahwa anak mereka akan mampu menjadi pribadi yang mandiri.

\section{Manfaat Coping}

Orang tua melihat bahwa usaha yang dilakukan membuahkan hasil terutama pada aktivitas keseharian yang lebih terlihat semakin normal. Hasil dari usaha yang sudah dilakukan oleh orang tua selama ini seperti memberikan terapi intensif serta menyekolahkan anak, dinilai memberikan manfaat langsung terhadap kemajuan kemampuan verbal, serta kemandirian anak autisme.

Selain manfaat pada diri anak autisme, manfaat langsung kepada diri orang tua dari coping yang telah dilakukan ialah, adanya perubahan terhadap penataan emosi yang semakin teratur. Informan juga merasa lebih dekat dengan keluarga dikarenakan aktivitas sehari-hari yang tentunya lebih banyak dihabiskan dengan keluarga.

\section{METODE PENELITIAN}

Penelitian ini menggunakan desain kualitatif dengan pendekatan fenomenologis, di mana peneliti mengidentifikasi hakikat pengalaman manusia tentang suatu fenomena tertentu (Moustakas, dalam Creswell, 2010). Pemilihan informan dalam penelitian dipilih secara purposive. Informan dalam penelitian ini adalah orang tua yang memiliki anak autisme dengan karakteristik: a) orang tua (ayah dan ibu) yang memiliki anak autisme; b) anak telah terdiagnosa menderita autisme sejak usia balita, c) berdomisili di Pekanbaru; d) memiliki bukti autisme atau hasil diagnosa dari terapis.

Metode pengumpulan data yang peneliti gunakan dalam penelitian ini ialah wawancara mendalam dan catatan lapangan. Metode pengumpulan data yang utama dalam penelitian ini adalah 1) wawancara, merupakan percakapan dan tanya jawab yang diarahkan untuk mencapai tujuan tertentu; 2) catatan lapangan berupa catatan tertulis tentang apa saja yang didengar, dilihat, dialami, dan dipikirkan dalam rangka pengumpulan data dan refleksi terhadap data (Moleong, 2013).

Validasi dan realibilitas data dilakukan dengan menggunakan metode triangulasi. Sugiyono (2013) mengartikan triangulasi sebagai pengecekan data dari berbagai sumber dengan berbagai cara, dan berbagai waktu. Dalam penelitian ini menggunakan triangulasi waktu dan triangulasi sumber. 
Ada empat (4) langkah yang dilakukan dalam analisis data penelitian. Pertama Epoche, menyingkirkan prasangka, penyimpangan tentang bentuk opini terhadap sesuatu. Kedua, tahap reduction yaitu menggambarkan kalimat yang terpola mengenai apa yang dilihat, tidak hanya objek eksternal tapi juga tindakan internal, kesadaran, dan pengalaman itu sendiri. Proses reduction dilakukan dengan Bracketing dan Horizontaliting data penelitian. Ketiga, Imaginative variation, mencari makna yang memungkinkan melalui penggunaan imajinasi, pembedaan berbagai referensi, pengelompokan dan pembalikan, pendekatan phenomenon dari perspektif yang divergen, posisi, peran-peran atau fungsi berbeda. Terakhir, melakuan synthesis of meaning dan ensenses, yaitu mengembangkan uraian secara keseluruhan dari fenomena yang ada sehingga menemukan esensi dari fenomena tersebut. Lalu mengembangkan fenomena yang terjadi pada responden dan menjelaskan bagaimana fenomena terjadi.

Tabel 2. Profil Informan Penelitian

\begin{tabular}{|c|c|c|c|c|c|c|c|}
\hline No & Nama & Status & $\begin{array}{r}\text { Usia } \\
\text { (th) }\end{array}$ & $\begin{array}{l}\text { Usia } \\
\text { Anak } \\
\text { (th) }\end{array}$ & $\begin{array}{c}\text { Usia Anak } \\
\text { Saat } \\
\text { Diagnosa }\end{array}$ & $\begin{array}{l}\text { Perilaku Dominan } \\
\text { Anak yang tampak }\end{array}$ & $\begin{array}{c}\text { Diagnosa } \\
\text { Awal } \\
\text { Pada } \\
\text { Anak }\end{array}$ \\
\hline 1 & $\mathrm{ACD}$ & $\begin{array}{l}\text { Istri } \\
\text { IHR }\end{array}$ & 36 & 7 & 1,5 & $\begin{array}{l}\text { 1. Kurangnya } \\
\text { timbalbalik sosial; } \\
\text { 2. Kurangnya } \\
\text { komunikasi secara } \\
\text { verbal }\end{array}$ & PDD-NOS \\
\hline 2 & IHR & $\begin{array}{c}\text { Suami } \\
\text { ACD }\end{array}$ & 37 & 7 & 1,5 & $\begin{array}{l}\text { 1. Kurangnya timbal } \\
\text { bailk kan sosial; } \\
\text { 2. Kurangnya } \\
\text { komunikasi secara } \\
\text { verbal }\end{array}$ & PDD-NOS \\
\hline 3 & DD & $\begin{array}{l}\text { Istri } \\
\mathrm{AR}\end{array}$ & 47 & 15 & 2,5 & $\begin{array}{l}\text { 1. Kurangnya } \\
\text { timbalbalik sosial; } \\
\text { 2. Kurangnya } \\
\text { komunikasi secara } \\
\text { verbal; } \\
\text { 3. Ketiadaan kontak } \\
\text { mata }\end{array}$ & Autisme \\
\hline 4 & $\mathrm{AR}$ & $\begin{array}{c}\text { Suami } \\
\text { DD }\end{array}$ & 53 & 15 & 2,5 & 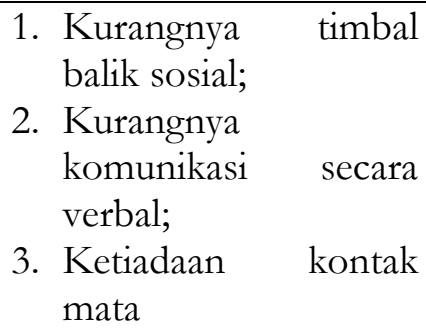 & Autisme \\
\hline
\end{tabular}




\section{HASIL DAN PEMBAHASAN}

Kehadiran anak penyandang autisme ditengah keluarga tentu akan mempengaruhi kehidupan seluruh anggota keluarga terutama orang tua. Adanya kesulitan dalam menangani anak autisme yang sering mengamuk, hiperaktif, dan berteriak sepanjang hari menyebabkan perasaan tidak menyenangkan sesekali muncul (Salamah, 2012). Belum lagi ketika orang tua harus berdamai dengan lingkungan yang belum tentu mampu menerima serta mengerti kodisi anak dengan baik, menyebabkan orang tua merasakan kekesalan dan enggan untuk membawa anak keluar rumah. Hal senada ditemukan dalam penelitian Pujiani (2007), bahwa partisipan terkadang merasa malu karena memiliki anak autisme. Rasa kecewa juga stres kerap dirasakan ketika melihat buah hatinya dipermainkan dan diejek orang gila oleh teman-teman sebayanya.

Adanya kendala-kendala yang kerap dialami, menuntut orang tua agar dapat menemukan usaha penyelesaian yang tepat. Penyelesaian masalah atau disebut juga dengan coping, pada dasarnya didefinisikan sebagai upaya yang fleksibel untuk mengelola stress (Lazarus \& Lazarus, 2006). Menurut Lazarus dan Folkman (1987), terdapat dua jenis coping yaitu Problem Focused Coping dan Emotional Focused Coping. Sementara Compton (2005) menjelaskan bahwa ada tiga (3) sub tipe coping yaitu usaha untuk mengubah emosi negatif/emotion-focused, usaha untuk mngubah situasi yang menyebabkan stres/problem-focused, dan usaha untuk menghindari masalah/avoidance.

Laki-laki dan perempuan memiliki perbedaan dalam menggunakan coping, sesuai dengan karakteristik dan kepribadian yang dimiliki. Demikian juga halnya dengan orangtua. Ibu cenderung melakukan coping yang berfokus upaya untuk mencari pokok masalah dan berusaha untuk menyelesaikannya/problem focused coping. Hal ini dilakukan ibu untuk mengurangi stresor yang ada. Ketika ibu menyadari bahwa anak menunjukkan ketidakwajaran dalam perilaku seperti ketiadaan respon terhadap lingkungan sekitar ataupun stimulus yang diberikan, serta ketidakmampuan anak dalam berkomunikasi selayaknya anak normal diusia perkembangannya, langkah yang diambil oleh para ibu adalah membawa anak ke dokter ataupun ahli untuk menjalani pemeriksaan terhadap tingkah laku anak.

Ketika anak didiagnosa mengidap autisme, ibu segera mencarikan tempat terapi serta sekolah untuk anak sebagai upaya penyembuhan. Selain itu, ibu juga menggali beragam informasi terkait autisme dari berbagai sumber seperti buku, internet, bahkan 
menghadiri seminar-seminar tentang autisme. Bertanya serta berdiskusi dengan anggota keluarga mengenai penanganan yang tepat untuk anak, serta berdoa kepada Tuhan juga dilakukan oleh ibu. Meski begitu, adakalanya ibu juga melakukan coping yang berpusat pada emosi seperti menyalahkan diri sendiri atas kondisi anak yang autisme. Dunahoo, Geller \& Hobfoll (1996) dalam penelitiannya menjelaskan bahwa, perempuan akan melakukan upaya pengatasan masalah sebagai bentuk rasa tanggung jawabnya sebagai ibu dan istri yang baik. Ibu lebih banyak menghabiskan waktu dua kali lebih banyak dibandingkan laki-laki dalam pengasuhan anak-anak walaupun mereka juga bekerja di luar rumah.

Sebagai ibu yang juga bekerja, mereka merasakan tekanan pribadi yang menyebabkan mereka merasa bersalah, sehingga berupayah keras untuk menjadi ibu yang terbaik bagi anak-anak mereka. Pines dan Aronson ,\& Kafry (1981) dalam penelitiannya menjelaskan ketika ibu merasa tidak dapat memenuhi semua tanggung jawab mereka sebagai ibu, maka dengan sekuat tenaga mereka percaya bahwa selain menjadi super profesional, mereka harus menjadi ibu yang super dan istri yang super bagi anak dan suami mereka.

Tidak demikian dengan ayah, coping yang dilakukan oleh ayah lebih kepada pengatasan masalah yang berfokus pada emosi /emotional focused coping. Hal ini dilakukan sebagai upaya untuk mengatur respon emosi terhadap situasi stres yang dialami, dalam hal ini kondisi anak yang mengalami autisme dianggap sebagai situasi yang harus direspon emosi secara positif. Ketika mengetahui anak yang dinantikan kehadirannya menderita autisme, ayah tidak serta merta mampu menerima dengan lapang dada. Terlebih ketika ayah yang memang kurang memiliki pengetahuan mengenai autisme, serta tidak adanya riwayat autisme dalam keluarga, menyebabkan munculnya penolakan dalam diri terhadap kondisi anak.

Pada awalnya, ayah sempat membandingkan perkembangan anak dengan yang lain seusianya serta menganggap bahwa tidak ada yang salah pada diri anak. Namun, perlahan ayah mampu memahami keadaan anak setelah mendapat penjelasan dari istri, maupun para ahli/terapis autis. Ayah juga melihat adanya sisi positif pada diri anak yang meski menderita autisme, anak memiliki keadaan fisik yang normal serta tidak mengidap gangguan lain yang menyertai. Meski coping yang dilakukan ayah pada umumnya lebih berfokus pada orientasi emosi, ada saat dimana ayah juga melakukan coping yang berfokus pada masalah seperti berdoa kepada Tuhan mengenai masa depan serta 
kesembuhan anak. Ayah yakin bahwa, doa adalah senjata ampuh yang dapat membantunya untuk lebih ikhlas menerima kondisi anak.

Namun, yang menarik dari hasil penelitian ini adalah temuan penelitian yang bertolak belakang dengan pendapat Lazarus dan Folkman (1980). Dimana Lazarus dan Folkman mengasumsikan bahwa laki-laki lebih cenderung menggunakan problem focused coping sementara perempuan lebih cenderung menggunakan emotional focused coping sebagai upaya pengatasan dari situasi-situasi stres. Asumsinya, laki-laki lebih aktif dan langsung pada pokok penyelesaian masalah terhadap stesor apapun, sementara disisi lain, perempuan yang lebih pasif dalam menghadapi masalah hanya mengkhawatirkan perasaan mereka dan dengan demikian gagal mengatasi masalah yang terjadi.

Dalam penelitian ini, justru sebaliknya, laki-laki cenderung berorintasi pada emotional focused coping perempuan lebih berorientasi pada problem focused coping. Hal ini terjadi karena, ibu lebih merasa memiliki tanggungjawab yang lebih besar dalam merawat dan mengasuh anak dibanding ayah, dan hal ini bukan berarti ayah tidak peduli terhadap pengasuhan anak. Sebagai orangtua yang memiliki anak autis akan memiliki serangkaian proses dalam menentukan coping mana yang digunakan untuk menghadapi anak autis mereka. Tekanan-tekanan yang disebabkan karena kondisi anak mereka yang mengalami autisme menyebabkan orangtua berupaya untuk melakukan tindakan tertentu sebagai strategi pengatasan masalah agar mereka keluar dari situasi yang tidak menyenangkan tersebut.

Orang tua melakukan serangkaian upaya untuk mengatasi permasalahan yang mereka hadapi dengan anak yang autisme, seperti meminta saran dari kerabat, serta mendatangi ahli seperti dokter untuk melakukan pemeriksaan pada perilaku anak yang dinilai orang tua mengalami gangguan. Mencari informasi-informasi terkait anak autisme dengan membaca buku, membaca majalah tentang autisme, menghadiri seminar-seminar yang membahas tentang autisme, serta mencari informasi melalui internet. Mengupayakan pemberian terapi pada anak untuk kesembuhan serta memilihkan sekolah yang tepat untuk anak.

Bentuk lain dari usaha penyelesaian yang dilakukan adalah berdoa kepada Tuhan, orang tua bahkan sudah melakukan perencanaan serta persiapan untuk masa depan kehidupan anak, seperti membangun ruko dan lapangan bulu tangkis yang hasilnya untuk keperluan anak, bahkan sudah mempersiapkan anak agar kelak mendapat pasangan. 
Selain itu, orang tua sempat menyalahkan diri sendiri atas kondisi anak yang autism, menolak keadaan autisme pada anak serta masih menganggap seolah anak tetap berkembang secara normal seperti anak seusianya. Namun disisi lain,orang tua kemudian mampu mengambil nilai positif dari kondisi anak yaitu, anak memiliki kondisi fisik yang normal meski terlahir dengan gangguan autisme.

Meski terkadang muncul perasaan kecewa dengan keadaan anak, lamat laun tumbuh kesadaran dalam diri orang tua bahwa sudah semestinya untuk belajar menjadi pribadi yang lebih bersabar. Mubarok (2009) menjelaskan bahwa bersabar merupakan ketabahan hati tanpa mengeluh dalam menghadapi godaan dan rintangan dalam jangka waktu tertentu, dalam rangka mencapai tujuan. Proses pemberian terapi pada anak yang panjang, usaha untuk mengulang materi terapi di rumah setiap harinya, serta menerima kenyataan bahwa anak akan selamanya hidup dengan autisme menjadi pemicu orang tua untuk lebih bersabar.

Selain bersabar, bertemu dengan orang tua lain yang memiliki anak dengan gangguan yang lebih parah, menyadarkan orang tua bahwa meskipun anak yang dilahirkan menderita autisme, namun anak masih dikaruniai fisik yang sempurna serta tidak mengalami gangguan tambahan lain. Hal ini menimbulkan rasa syukur dalam diri orang tua. Bryant (1989) \& Langston (1994) mengatakan bahwa rasa syukur merupakan kecenderungan untuk menghargai dan menikmati setiap peristiwa dan pengalaman (dalam Snyder \& Lopez, 2007)

Dalam proses pemaknaan usaha yang dilakukan, serta penerimaan orang tua terhadap kondisi anak autisme, tidak terlepas dari dukungan sosial. Cobb, dkk (1976dalam Sarafino, 1997) mengatakan bahwa dukungan sosial mengacu pada kenyamanan, kepedulian, harga diri, atau membantu seseorang untuk menerima dari kelompok lain. Orang tua merasa banyak memperoleh banyak bantuan terutama dari terapis dan guru-guru ditempat anak autisme bersekolah. Selain itu, bantuan dari keluarga juga dinilai sangat dibutuhkan. Ketika orang tua merasa lelah menjaga anak autisme, maka pihak terdekat yang siap membantu adalah keluarga. Teman-teman dalam lingkup kehidupan sosial orang tua juga memberikan dukungan seperti sesekali memberikan pujian kepada orang tua ketika melihat adanya kemajuan perkembangan pada anak autisme. Greenglass (1993) dalam penelitiannya menjelaskan untuk mengurangi tekanan-tekanan dan mengatasai perasaan bersalah, mengatasi bentuk seperti angan-angan dan menyalahkan diri sendiri, kaum perempuan lebih mudah untuk 
mencari dan mendapatkan dukungan sosial dari teman-teman dan anggota keluarga dibandingkan laki-laki. Hal ini terjadi karena perempuan merasa bahwa tanggung jawab mereka dalam hal pengasuhan anak lebih besar daripada laki-laki. Sehingga menyebabkan para ibu berusaha untuk menjadi ibu yang baik dan bertanggung jawab atas anak-anak mereka dan ibu akan berusaha untuk mencari berbagai informasi demi kesembuhan anak mereka. Walaupun sebenarnya ayah juga memiliki tanggung jawab yang sama besarnya dalam pengasuhan anak.

Orang tua juga merasakan adanya manfaat dalam kehidupan sehari-hari sebagai hasil dari usaha yang telah dilakukan selama ini. Orang tua merasakan adanya perubahan dalam diri sendiri mengenai penataan emosi yang mulai membaik. Orangtua memaknai coping yang dilakukan sebagai sebuah media untuk melatih kesabaran dan kebersyukuran atas karunia anak yang telah dititipkan Allah SWT kepada mereka. Kesabaran dan rasa syukur atas kehadiran anak, membuat orangtua selalu optimis untuk mencari dukungan sosial baik dukungan informasi maupun dukungan emosional dari orang lain. Dalam hal ini ibu lebih optimis dalam mengupayakan tritmen-tritmen yang dapat membantu anaknya untuk sembuh. Sementara ayah lebih sabar dalam memperlakukan anak mereka, dan mencoba untuk lebih mengerti dan memahami anak.

Selain itu, coping yang dilakukan orang tua mendatangkan manfaat yang luar biasa, baik bagi anak maupun bagi anak autis itu sendiri. Manfaat coping yang dilakukan orang tua juga terlihat ada pada peningkatan dan perkembangan kemampuan verbal serta perubahan perilaku anak sebagai hasil dari mengikuti terapi yang telah diberikan secara konsisten. Artinya, kemauan orang tua untuk menerima kondisi anak mereka, mencarikan berbagai sumber informasi untuk mencari tempat terapi yang tepat bagi anak, serta perlakuan orang tua terhadap anak sangat jelas hubungannya dengan kemajuan yang sangat signifikan pada anak. s. Sehingga, pemaknaan orang tua terhadap upaya yang dilakukannya dalam mengasuh, merawat dan mendidik anak autis adalah sebagai sebuah wadah yang dapat melatih kesabaran diri, meningkatkan rasa kebersyukuran dengan terus berupaya mencari informasi untuk kesembuhan dan perkembangan anak yang sehat. Dengan demikian, coping yang dilakukan oranngtua baik coping dalam bentuk problem focused coping maupun emotional focused coping merupakan upaya yang dilakukan oleh orangtua untuk menerima, bertoleransi dan meminimalkan tekanan-tekanan yang dirasakan sehingga akan dapat menjaga keseimbangan hidup. 


\section{E. Simpulan}

Pemaknaan coping pada orang tua yang memiliki anak autis adalah melatih kesabaran dan perwujudan rasa syukur atas anugerah anak yang diberikan. Hasil penelitian ini juga menunjukkan bahwa terdapat perbedaan kecenderungan bentuk coping yang dilakukan ayah dan ibu. Ibu lebih cenderung melakukan coping yang berfokus langsung pada masalah dan menghadapi sumber stress/problem focused coping, sementara ayah lebih cenderung melakukan copingy ang berfokus pada upaya untuk mengurangi tekanan-tekanan melaui respon emosional terhadap apa yang dirasakannya/emotional focused coping. 


\section{DAFTAR REFERENSI}

Aisyah, S., Pengaruh Pola Asuh Orang Tua Terhadap Tingkat Agresivitas Anak. Jurnal MEDTEK, Vol. 2, No. 1, 2010.

Amalia, Desy, Studi Kasus Mengenai Coping Stress Pada Orangtua Dari Remaja Autisme di Kota Bandung. Fakultas Psikologi Universitas Kristen Maranatha., 2012.

Compton, W.C., An Introduce to Possitive Psychology. USA: Thompson Wadsworth, 2005.

Creswell, John W. Research Design Pendekatan Kualitatif, Kuantitatif, dan Mixed. Diterjemahkan Oleh: Achmad Fawaid.Yogyakarta: Pustaka Pelajar, 2010.

Davidson, Gerald C., Neale, John M., Kring, Ann M, Psikologi Abnormal (edisi ke-9). Diterjemahkan Oleh: Noermalasari Fajar. Jakarta: Rajawali Pers, 2010.

Dunahoo, Carla L., Geller, Pamela A., Hobfoll, Women's Coping: Communal versus Individualtic Orientataion. Chapter 9 in Handbook of Work and Health Psychology. England: John Wiley, 1996.

Dunn, M. E., Burbine, T., Bowers, C. A., \& TantleffDunn, S. Moderators of stress in parents of children with autism. Community Mental Health Journal, 37, 2001.

Diagnostic And Statistical Manual of Mental Disorder. Fourth Edition: Text Revision. American Psychiatric Association: Arlington, VA., 2000.

Folkman, S., Lazarus, Richard S, An analysis of Coping in a Middle-Aged Community Sample. Journal of health and Social Babaviour, 21, 1980.

Goldenberg, W.A., Greenberger, W., Hamili, S., O’Neil R. Role Demands in The Lives of Employed Single Mothers With Preschoolers. Journal of Family Issues, 13, 1992.

Greenglass, E.R. The Contribution of Social Support to Coping Strategies. Applied Psychology: An International Review, 42, 1993.

Hasanah, Neneng, Gambaran Sikap Orang Tua Yang Mempunyai Anak Autisme. Fakultas Psikologi Universitas Islam Negeri Syarif Hidayatullah, 2007.

Hurlock, Elizabeth B, Psikologi Perkembangan: Suatu pendekatan sepanjang rentang kehidupan (ed. Ke-5). Jakarta: Erlangga, 2000. 
Hastuti, Leonilla D \& Taganing K, Ni Made, Coping Stress On Maternal And Child Autisma. Fakultas Psikologi Universitas Gunadarma, 2007.

Lazarus, Richard S, Coping Theory and Research: Past, present, and Future. Psychosomatic Medicine 55, 1993.

Lazarus, Richard S., Folkman, Susan.,Stres, Appraisal, and Coping. New York: Springer Publishing Company, Inc., 1984.

Lazarus, Richard S., Lazarus, Bernice N, Coping With Aging. New York: Oxford University Press, Inc., 2006.

Lubis, Misbah U Penyesuaian Diri Orang Tua Yang Memiliki Anak Autis. Skripsi. Medan: Fakultas Psikologi Universitas Sumatera Utara, 2009.

Mancil, G. Richmond., Boyd, Brian A., Bedesem, Pena, Parental Stress and Autism: Are There Useful Coping Strategies?. Education and Training in Developmental Disabilities, 2009, 44(4), 2009.

Moleong, Lexy J, Metodologi Penelitian Kualitatif. Bandung: PT. Remaja Rosdakarya, 2013.

Mubarok, Achmad, Psikologi Islam. Jakarta: The International Institute of Islamic Thought (The IIIT) dan Wahana Aksara Prima (WAP), 2009.

Mulyana, Deddy, Metodologi Penelitian Kualitatif (Paradigma Baru Ilmu Komunikasi dan Ilmu Sosial Lainnya). Bandung: PT. Remaja Rosdakarya, 2006.

Muniroh, Siti M, Dinamika Resiliensi Orang Tua Anak Autis. Jurnal Penelitian, Vol. 7 No. 2, 2010.

Nevid, Jeffrey S., Rathus, Spencer A., Greene Beverly, Psikologi Abnormal (jilid 2). Diterjemahkan Oleh: Dr. Jeanette Murad, dkk. Jakarta: Penerbit Erlangga, 2005.

Poerwandri, E. Kristi, Pendekatan Kualitatif Untuk Penelitian Perilaku Manusia (cetakan ke-5). Depok: Lembaga Pengembangan Sarana Pengukuran dan Pendidikan Psikologi (LPSP3), 2013.

Pines, A.M., Aranson E., Kafry, Burnout: From Tedium to Personal Growth. New York: Free Press, 1981.

Prastowo, Dion Y, Penyesuaian Diri Pegawai Dalam Menghadapi Perubahan Organisasi.Fakultas Psikologi Universitas Muhammadiyah Surakarta, 2014. 
Pujiani, Helena, Dampak Psikologis Orang Tua Yang Mempunyai Anak Autis. Skripsi. Semarang: Fakultas Psikologi Universitas Katolik Soegijapranata, 2007.

Qodariah, Siti., Nurlailiwangi, Eneng., Amelia, Silva, Peran Psikolog Dalam Meningkatkan "Coping Strategy" dan Adaptional Outcomes" Pada Ibu Yang Memiliki Anak Autis. Bandung: Fakultas Psikologi Universitas Islam Bandung, 2011.

Ramadhany, R \& Marettih, Anggia K, Strategi Koping Pada Ibu Dengan Anak Autis.Jurnal Psikologi Vol. 5, No. 2, 2009.

Salamah, Afshyus. Gambaran Emosi Dan Regulasi Emosi Pada Remaja Rang Memiliki Saudara Kandung Penyandang Autis. Universitas Gunadarma, 2012.

Sarafino, Edward P, Health Psychology (Biopsychological Interactions), Third Edition. New York: John Wiley \& Sons, Inc., 1997.

Sarafino, Edward P, Health Psychology: Biopsychosocial Interaction, Second Edition. New York: John Wiley \& Sons, Inc., 2006.

Schabracq, Marc. J., Winnubust, Jacques, A.M., Cooper, Cary L, Handbook of Work and Health Psychology. England: John Wiley, 1996.

Snyder, C.R., Lopez, Shane. J,.PositivePsychology(The Scientific and Practical Explorationsof Human Strength). California: Sage Publications, Inc., 2007

Sugiyono, Metode Penelitian Kuantitatif, Kualitatif, Dan R\&D. Bandung: Alfabeta, 2014.

Taylor, Shelley E, Health Psychology, Ninth Edition. New York: McGraw-Hill Education, 2011.

Vitaliano, P.P., Maiuro, R.D., Russo, J., Katon, W., De Wolfie, D., Hall, G., Coping Profiles Associated With Psychiatric, Physical Health, Work and Family Problems.Health Psychology, 9, 1990.

Wardani, Desi S, Strategi Coping Orang Tua Menghadapi Anak Autis. Indigenous, Jurnal Ilmiah Berkala Psikologi Vol. 11, No. 1, 2009. 